\title{
Análise Físico-Quimica do Leite de Vacas Alimentadas com Cama de Frango
}

Marco Antônio Gonzales de Carvalho (I), Priscilla Camilla Zucco dos Santos (I), Germano Francisco Biondi (I), Otávio Augusto Martins

(I), Adriele Nayara Dias Ishizuka (I), Juliana Célia Denadai (I), Isabella Goulart Oliveira da Silva (I), Rodrigo da Silva Silva Gennari (I), Matheus Betelli Piccolo (I), Carlos Ducatti (I)

(I) UNESP - Universidade Estadual Paulista (Distrito de Rubião Junior, s/n )

\section{Resumo}

O uso da cama de frango na alimentação de ruminantes é proibido em diversos países, devido aos riscos de transmissão de doenças, principalmente da Encefalopatia Espongiforme Bovina. Apesar disso, ainda é fornecida como alimento a ruminantes, incluindo as vacas leiteiras. Devido à grande importância do leite na alimentação humana, e a difícil detecção do uso de cama de frango nas dietas de ruminantes, o objetivo desse estudo foi avaliar possíveis alterações físico-químicas no leite de vacas alimentadas com cama de frango. Foram utilizadas 12 vacas girolanda, distribuídas em dois tratamentos: vegetal (com dieta contendo silagem de milho, silagem de grão úmido de milho e farelo de soja) e cama de frango (contendo silagem de milho, silagem de grão úmido de milho e cama de frango). A execução do projeto foi autorizada legalmente pelo Ministério da Agricultura, Pecuária e Abastecimento sob $\mathrm{n}^{\circ}$ de processo 21052.009187/2013-02. Foram coletadas amostras de leite no 56 dia experimental. As composições físico-químicas das amostras foram determinadas pelo equipamento Milktester e os dados analisados pelo procedimento GLM no programa Minitab16. Não houve diferenças significativas nos valores de crioscopia $\left(-0,525\right.$ e $\left.-0,581^{\circ} \mathrm{H}\right)$, densidade (1,0288 e 1,0308), lipídeos (4,5 e 4,1\%), sólidos totais (12,68 e 13,55\%), 
lactose $(3,3$ e $3,5 \%)$, proteína $(4,6$ e 4,9\%) e sais $(0,7$ e $0,7 \%)$, entre os tratamentos cama de frango e vegetal, respectivamente. No entanto, o valor de sólidos não gordurosos foi $10,3 \%$ menor $(p<0,05)$ no leite das vacas alimentadas com cama de frango $(8,46 \%)$ em comparação ao leite do tratamento vegetal $(9,43 \%)$, provavelmente pela menor quantidade de proteína, lactose e sais no leite das vacas do tratamento cama de frango e maior quantidade de lipídeos. Isto pode ter ocorrido devido a maior quantidade de alimentos volumosos na dieta com cama de frango, que favorece a produção de acetato no rúmen e o aumento de gordura no leite. Os dados obtidos nesse estudo indicam que a análise físico-química do leite pode servir como ferramenta adicional a outras técnicas de detecção do fornecimento de cama de frango a vacas leiteiras.

Palavras-Chave: análises físico-químicas, cama de frango, leite Agência de Fomento: FAPESP Projeto Temático n 2008/57411-4 